\title{
Tyrkisk uden tårer?
}

\section{Henrik Døcker}

\section{Hele to bøger på det danske bogmarked påtager sig at forklare, at Tyrkiet betragter sig som europæisk salonfähigt. Begge beskriver meget overordnet sådanne vigtige nutidshistoriske fænomener som folkedrabet på armenierne, torturen af kurderne og Cypern-problemet}

Andrew Mango: Tyrkerne - Arven efter Atatürk. Roskilde Universitetsforlag 2004, 298 sider.

Jesper Møller Sørensen og Erik Boel: Tyrkiet - på vej gennem EU's nåleøje. Gyldendal 2005, 392 sider.

Vi har måttet vænne os til, at geografi og politik ikke altid er sammenfaldende, og særlig ikke når det gælder Europas udstrækning. Fx henregnes Cypern til Europa uanset at det på grund af den asiatiske fastlandssokkel ligger i Asien. Både dette land og Tyrkiet er efterhånden gamle medlemmer af Europarådet de har politisk antennerne rettet mod Europa. Den langt fra afsluttede diskussion om, hvorvidt Tyrkiet også er et naturligt kommende medlem af Den Europæiske Union er med disse to bøger blevet forsynet med kraftfulde apologeter, ja så overvældende, at man næsten må undres over, at det ikke er det officielle Tyrkiet, der har udsendt bøgerne.

Nuvel, to af forfatterne har i hvert fald haft Tyrkiet "inde under huden": Andrew Mango, der bor i London, fødtes i Istanbul, behersker tyrkisk og har i en lang årrække (194786) været BBC's korrespondent i Tyrkiet, og Jesper Møller Sørensen var som dansk diplomat udstationeret i Ankara i perioden 2000-2003.

Det har i begge bøger resulteret i meget behjertede forsøg på at forklare hvad kemalismen, hint ærketyrkiske fænomen, egentlig står for. Den form for statsdannelse, som den tidligere general Mustafa Kemal, der som civil statsmand tog navnet Atatürk ("tyrkernes fader"), 
beskrives dog som oftest i negative termer, altså ved alt det, den ikke er: Nemlig antiklerikal, ikke-arabisk, men naturligvis også vest(europa) vendt, moderne.

Det Osmanniske Riges folkedrab på omkring én million armeniere i 1915 behandles uhyre kursorisk, ja efter min mening decideret ufuldstændigt i begge bøger. Møller Sørensen/Boel erkender dog, at det er en fremherskende opfattelse hos historikere, at osmannerne både i 1891 og 1915 foretog brutale overgreb, ja ligefrem folkedrab på denne befolkningsgruppe, men de angiver ikke noget anslået tal på dødsofre og sætter gåseøjne omkring ordet folkedrab.

Mango henviser nærmest en passant til "folkedrabskampagnen" samtidig med at han gør opmærksom på, at tyrkere og kurdere også måtte lade livet. Han sammenblander uden at beskrivelsen er særlig tydelig - ofre for krigeriske begivenheder i Det Osmanniske Rige med den regulære fordrivelse og nedslagtning af armenierne, som stribevis af historikere har påvist, herunder udslettelse af rene armenske landsbyer i Anatolien.

Møller Sørensen/Boel, der begge er cand. scient. pol., forklarer overskueligt, hvordan Sèvres-freden i 1920 på det nærmeste blev en gravsten over Det Osmanniske Rige, idet dets territorium efter denne traktat indskrænkedes ved en planlagt afståelse af betydelige områder mod øst til en hhv. kurdisk og armensk stat.

Mustafa Kemal, der oprindelig var udsending for sultanen i Istanbul, fik da skabt en større modstandsbevægelse i Anatolien, hvad der i 1923 førte til den for Tyrkiet langt gunstigere Lausanne-traktat. Al tale om et selvstændigt Kurdistan forstummede, armenierne måtte realisere sit nationale særpræg inden for den nye stat Sovjetunionen, men fik dog, modsat kurderne, i 1991 omsider selvstændighed.

Atatürk og hans mangeårige premierminister (siden hen præsident) Ismet Inönü fik ved grundlæggelsen af den tyrkiske republik i 1923 som opgave at opbygge en nation.

\section{Forkvaklede partidannelser}

Det er næppe overdrevent at kalde denne koncentration om "én stat, ét folk, ét sprog...” en besættelse, som trækker sine blodige spor den dag $\mathrm{i}$ dag. Som taberstat efter Første Verdenskrig, martret af krigens ødelæggelser, tvang den autokratisk anlagte Atatürk alskens moderniseringer ned over det "nye" tyrkiske folk, det være sig det latinske alfabet, mænds og kvinder klædedragt, men først og fremmest cementeringen af den verdslige stat gennem en franskpræget lovgivning renset for alle elementer af sharia.

Først efter Anden Verdenskrig indførtes et flerpartisystem i Tyrkiet. Det $t ø r$ siges, at lige akkurat dette 
for en demokratisk stat så væsentlige element har affødt overordentlig mange problemer, ja i flere perioder skabt voldsom uro og udløst undtagelsestilstand. Hele tre gange har militæret grebet ind ikke ved et traditionelt statskup, men som en magtfuld faktor til midlertidig beskyttelse af demokratiet med hårdhændede midler.

Tyrkisk parlamentarisk liv er beretningen om utallige partier, der er blevet forbudt, politikere, der har været i politisk karantæne, uendelige rækker af fængslinger af folk, som sagde det forkerte, tog kurdernes parti eller fandtes at have ærekrænket Atatürks tyrkiske nation.

Ingen af bøgerne redegør for eller analyserer nærmere den politiske infantilisme, som gang på gang har foranlediget hæren til midlertidigt at tage magten. Samtidig med at venstreorienterede er blevet forfulgt, torteret og fængslet i stor stil. Den europæiske bremse, der så at sige er blevet benyttet mod Tyrkiets værste udskejelser ved mistænkeliggørelse af alle mulige politiske partier og ved brutal nedkæmpelse af kurdernes kamp for en slags national mindretalsbeskyttelse, får en stedmoderlige omtale i begge bøger. Jeg skal gøre opmærksom på, at Den Europæiske Menneskerettighedsdomstol i Strasbourg i langt over 100 tilfælde har statueret tyrkisk brud på torturforbuddet og retten til livet (dvs. har foretaget henrettelser uden dom), og at Tyrkiet i alle tilfælde har betalt erstatninger til ofrene. Ret skal være ret: Boel/ Møller Sørensen redegør redeligt for forfølgelser af og drab på kurdere, men beskriver ikke tydeligt omfanget heraf, Mango nævner end ikke Strasbourg-domstolen ved navn.

Mango, hvis bog i modsætning til Møller Sørensen/Boel byder på et stikordsregister, har ikke fundet det nødigt at optage ord som menneskerettigheder, tortur, korruption eller Sères i registret, selv om nogle af disse emner dog er beskrevet.

Mango er tydeligvis ilde berørt ved at måtte omtale torturen: "Den store opmærksomhed omkring anklager om tortur og andre krænkelser af menneskerettighederne i Tyrkiet og den hyppige brug af disse anklager i politisk snarere end humanitært øjemed gør det vanskeligt at vurdere om Tyrkiet faktisk fortjener mere kritik i denne henseende end for eksempel andre lande, som venter på optagelse i EU", skriver han.

Jeg vil anbefale ham at slå op på www.echr.coe.int, hvor man lynhurtigt kan forvisse sig om, at Tyrkiet har været trukket for menneskerettighedsdomstolen over 200 gange for krænkelse af den europæiske menneskerettighedskonventions art. 2 og 3.

Derimod pointerer Mango, at 40.000 politibetjente fik disciplinærstraffe og 1000 blev afskediget blot på et halvt år i 2003. Han tilføjer dog senere, at kun 113 af 
1500 politifolk, anklaget for fangemishandling i et kvartal i 2000, rent faktisk blev dømt. Vigtigere end statistik er nok oplysningen, om at politifolk nu modtager undervisning i menneskerettigheder. (jeg vil tilføje: fx i ikke at tæve arrestanterne - hvilken undervisning Europarådet, herunder Danmark, har bistået med at få indført).

\section{Kurderne anskues adskilt fra PKK}

Møller Sørensen/Boel skal anerkendes for deres meget grundige beskrivelser af tyrkernes holdninger til de vekslende politiske partiers indhold og til mindretal i det hele taget, dog især kurderne. De påpeger med rette, at det er kurdere, som lever uden for Tyrkiet, der har de mest yderligtgående synspunkter om selvstyre, ja undertiden ligefrem selvstændighed for Tyrkiets kurdere. Det har dog den naturlige forklaring, at det (stadig) er risikabelt i Tyrkiet selv at udtrykke markante meninger om retten til kurdisk egenart eller at tale det kurdiske sprog.

De to forfattere erkender, at det tyrkiske EU-medlemsperspektiv, der knæsattes i Helsinki 1999 - det man også kan kalde tilnærmelsesprocessen - kan blive afbrudt, med en ultranationalistisk bølge i Tyrkiet til følge. Mange tyrkere frygter ifølge Mango, at Tyrkiet går fra at være multietnisk til multikulturelt, og at dette kan give kurderne smag for at fremme separatistiske mål.
Begge bøger appellerer til omverdenen om et mere nuanceret syn på det kurdiske problem, herunder arbejderpartiet PKK's rolles om væbnet enhed. Mango påpeger, at der ikke er tale om, at den tyrkiske stat udnytter de kurdiske områder: Statens ikke-militære udgifter har altid været større end indtægterne fra disse områder.

Årsagerne til tilbageståenheden skal søges i geografien, topografien, de lavt uddannede mennesker, de primitive sociale strukturer. Kurderne afslår i vidt omfang at sende deres piger i skole, i 1989 fik kvinderne i Sydøsttyrkiet gennemsnitlig 5,7 børn, i den vestlige del 2,6.

Konfrontationerne mellem PKK og tyrkisk militær har ført til nedbrænding af ca. 3000 landsbyer, næsten alle kurdiske, og 35.000 mennesker har over en årrække mistet livet i træfninger. Mange kurdere er søgt ind til byerne, anfører Mango, uden at nævne årsagen.

Et alvorligt slag for PKK var det, at partiet i 2001 blev opført på EU's såkaldte terrorliste, og at det ikke hjalp det at tage navneforandring (det er sket to gange siden), men vigtigere er det formentlig, som påpeget af Boel/Møller Sørensen, at Tyrkiet langt om længe er begyndt at anskue kurderne adskilt fra PKK, idet enkelte politikere har udtalt en moderat accept af kurdernes eksistens.

Hertil er kommet en nyfortolkning af den nævnte Lausanne-trak- 
tat, der ikke - som hidtil officielt antaget - begrænsede antallet af anerkendte minoriteter til tre (hvoriblandt kristne og kurdere ikke var). PKK blev naturligvis også svækket ved anholdelsen i 1999 af sin mangeårige leder Abdullah Öcalan, der oprindelig blev dødsdømt, men siden dømt til livsvarigt fængsel.

Der savnes i begge bøger en mere overbevisende analyse af de mange tyrkiske partier, der er blevet forbudt af Forfatningsdomstolen, hvorefter de alle på nær ét (Refah-partiet) er blevet lovliggjort af Den Europæiske Menneskerettighedsdomstol. Bøgerne synes generelt at være mest optaget af at forklare tyrkernes og det officielle Tyrkiets holdninger til et bredt spektrum af problemer, mens en mere objektiv beskrivelse er trængt noget i baggrunden.

Mango leverer imidlertid vigtige informationer om økonomien, der er af betydning just for det brændbare, aktuelle spørgsmål: Mulighederne for at slippe ind i EU. Den Internationale Valutafond har således beregnet gennemsnitsindkomsten pr. tyrker til en fjerdedel af gennemsnittet i EU undtagen Grækenland, Portugal og Spanien og en tredjedel af gennemsnittet i de tre lande. For at undgå en forøget vækst i forskellen i indkomst pr. indbygger skal væksten i Tyrkiet være 4 pct. om året - i 1990'erne var den 3,1 pct., men i 20027,9 pct. og i 20035,8 pct.

Tyrkiets økonomi var i 2001 i en så alvorlig krise, at Den Internationale Valutafond (IMF) måtte træde til med lån, samtidig med at det tvang landet til at indføre et strengere banktilsyn.

\section{“Tyrkertro" på EU}

Ifølge Mango har alle tyrkiske regeringer udvist inkompetence ved styring af større projekter. I 1980'erne og 90'erne blev der anlagt rørledninger til naturgas fra Iran og Rusland, siden blev det aftalt at aftage elektricitet fra et hydroelektrisk værk på floden Eufrat lige nord for grænsen til Syrien. Men da gas og el skulle begynde at strømme ind i Tyrkiet var landet kastet ud i en økonomisk krise, samtidig med at distributionsnettet ikke var færdigt.

Opgøret med kurderne har ifølge Mango fremmet en integration af Sydøsttyrkiet i den øvrige del af andet, herunder gennemførelsen af GAP (Det sydøstanatolske Udviklingsprojekt). Floderne Eufrat og Tigris udspringer begge i Tyrkiet og flyder senere gennem Syrien og Irak. GAP vil med tiden blive en meget betydningsfuld el-producent i Tyrkiet - i 1999 leverede det 13 pct. af al elektricitet i landet og 43 pct. af den vandbaserede elektricitet.

For den fortsat uafklarede konflikt om republikken Cypern bærer Tyrkiet en pæn del af skylden. Her som mange andre steder i de to bøger synes dog de lange linjer i forskellige udviklingsforløb ligesom at 
fortone sig i for mange detaljer uden klar analyse.

Tyrkiet intervenerede med militær på Nordcypern i 1974 til beskyttelse af den tyrk-cypriotiske befolkningsgruppe efter terroraktioner og myrderier fra græsk-cypriotisk side.

Det problematiske ligger $i$, at Tyrkiet nu har ladet 30 år gå uden at trække sine ca. 30.000 soldater tilbage derfra. Med international fordømmelse af denne løsrivelse fra republikken Cypern har Den Nordcypriotiske Republik alene levet på Ankaras politiske og økonomiske nåde, tusinder af tyrk-cyprioter er udvandret og fattige bønder fra det tyrkiske Anatolien indvandret.

Det er en underdrivelse - som Boel/Møller Sørensen gør det - at konstatere, "at Tyrkiet kunne have spillet sine udenrigspolitiske kort bedre". Nordcypern, som tilbage i begyndelsen af 1960'erne var Cyperns ypperste turistområde, er blevet forarmet og "tyrkiseret", næppe som følge af nogen tilsigtet politik, men for at få dyrket jorden og i det hele taget opretholde et samfundsliv, om end i et lavt gear.

Når Tyrkiet selv så gerne vil ind $\mathrm{i}$ EU, skyldes det fortsat drømmen om at blive "rigtigt" europæiseret, som påpeget af Boel/Møller Sørensen. Radikale islamiske kræfter og såkaldte hårdkogte kemalister har dog ihærdigt afvist tilnærmelsen til Europa.

Det er tankevækkende, at landet først i midten af 1990'erne ophæve- de en lov, hvorefter det gav en bøde på $100 \$$, hvis man som tyrk tog til udlandet uden officiel godkendelse. Andre eksempler på, at lovgivningen har hindret opkomsten af et frit civilsamfund er den indtil 1995 gældende lov, hvorefter ingen foreninger måtte have et politisk formål. Så sent som i 1999 blev 30 såkaldte ngo'er (ikke-statslige organisationer) forbudt. Betingelserne for privat foreningsdannelse er fremdeles rigoristisk.

Det er en trossag, om man vil hæfte sig ved at Tyrkiet som Mango skriver har "lommer af tilbageståenhed" eller - med Boel/Møller Sørensen skræmmes af, at "den ortodokse kemalisme" (dvs. nationalisme) fortsat er et kraftigt islæt i statsstrukturen.

Begge disse bøger er i nogen grad præget af ønsketænkning. De beskriver mange af det tyrkiske samfunds problemer og modsætningsfyldte facetter, men nærer så at sige en "tyrkertro" på at de næste ti år vil placere Tyrkiet i den kategori af stater, der efterlever retsstatens påbud om redelig regeringsførelse, meningsfuld menneskeretspolitik og sund samfundsøkonomi. Med andre ord: Egnet til EU.

Journalist Henrik Døcker har $i 40$ år
skrevet om international politik og ret
(folkeret) foruden menneskerettigheder $i$
dansk dagspresse såvel som en rekke
tidsskrifter. Han er forfatter til bl.a.
"Menneskeret i Europa” (2. udg. 2004). 